Александра Курленкова

\title{
“КОТЫ-МУРЗИКИ", «КАПРИЗНЫЕ БОЛЬНЫЕ» И “ТРАНСГРЕССОРЫ»: НЕЗРЯЧИЕ В «ПРОФЕССИОНАЛЬНОМ ОБЩЕСТВЕ» СКВОЗЬ ПРИЗМУ МОДЕЛЕЙ ИНВАЛИДНОСТИ
}

В статье предпринимается попытка посмотреть на участие незрячих в профессиональной жизни общества сквозь призму медицинской, социальной и трудовой моделей инвалидности. Каждая из этих моделей продукт социальной и юридической конвенции, который, однако, определяет государственную политику, (само)восприятие незрячих людей, в том числе в профессиональной сфере. На основе качественного анализа интервью с незрячими людьми, я показываю, что отношение к ним определяется медицинской (патерналистской) моделью инвалидности, конструирующей образ незрячего как больного, нуждающегося в покое и «домашнем режиме». Коммерческие компании не видят экономических преимуществ от найма «инвалидов», предпочитая выплачивать штрафы или использовать схемы фиктивного трудоустройства. Спектр легитимных профессиональных возможностей незрячих, сформировавшийся еще в СССР, крайне узок: это монотонная ручная работа на предприятиях, часто без договорной основы, за символическую оплату, не дотягивающую до минимального размера оплаты труда; профессиональные колеи незрячих включают сферу массажа, музыки, преподавания в коррекционных школах. В статье я показываю, что в основе выделения этих областей для работы незрячих лежит идея о том, что люди без зрения - это гомогенная группа, обладающая одинаковыми профессиональными способностями и желаниями. Многие незрячие следуют этим «протоптанным тропинкам»; однако некоторые люди с ограничениями зрения выступают в роли «трансгрессоров», преступающих привычные профессиональные маршруты и прокладывающие собственные.

Ключевые слова: модели инвалидности, незрячие, инвалиды, трудовое гражданство, медикализация, профессиональные колеи

Александра Сергеевна Курленкова - к.и. н., научный сотрудник группы медицинской антропологии ИЭА РАН, Москва, Россия. Электронная почта: askurlenkova@yandex.ru 
DOI: $10.17323 / 727-0634-2017-15-2-235-250$

Отношения между человеком без зрения и зрячими людьми опосредованы понятиями и значениями, через которые они смотрят друг на друга. Разделение на зрячих и незрячих, или юридически закрепленное различение инвалидов и общества (Ф3 1995), является продуктом социальной или культурной категоризации с заложенной в ней аксиоматикой и прагматикой. Такая категоризация контингентна, неслучайна и необязательна, в то время как разработанные в рамках disability studies (Johnstone 2001: 12) модели демонстрируют множественность взглядов на инвалидность.

Понимание инвалидности (или смежных конструктов) в исторических и локальных контекстах строилось на разных базовых метафорах. Отличия во внешности, поведении, эмоциональных реакциях человека могли рассматриваться в религиозных терминах как наказание за грехи, или, наоборот, свидетельство избранности (Добровольская 2016). Для анализа секулярных обществ исследователи предложили две ключевые модели: медицинскую, подчеркивающую биологический и индивидуальный характер увечья (ср., Freidson 1988: 249), и социальную, переносящую локус ответственности на физическое и социальное окружение, «инвалидизирующее» человека. Кроме того, я обращаюсь к трудовой модели инвалидности (production-related view of disability), разработанной Майклом Оливером (Oliver 1990), характеризующей политику инвалидности в советское время. В ней граница между инвалидом и не-инвалидом проводится по линии экономического вклада в производство товаров и услуг.

Задача статьи - показать возможные связи между тем, как фигура «инвалида» интерпретируется в различных моделях инвалидности, и тем, какое участие незрячие принимают в современном «профессиональном обществе» (см.: Московичи 1998: 126). Анализ проводится на нескольких уровнях. Во-первых, анализируются нарративы людей с ограничениями зрения, в которых тематизируются вопросы трудоустройства, а также более широкие общественные установки относительно «правильного» поведения человека с инвалидностью. В статье используются 23 биографических интервью с людьми, имеющими первую или вторую группу инвалидности по зрению1; дневниковые записи наблюдений, сделанные в организациях Всероссийского общества слепых (ВОС), центрах реабилитации (КСРК ВОС, Волоколамский центр реабилитации), нескольких местах работы (предприятие ручной сборки и колл-центр в Москве) и образования (Кисловодский медицинский колледж) людей с инвалидностью по зрению. В анализ включены нормативные документы, регулирующие трудоустройство людей с инвалидностью, статистические данные, а также интервью с администраторами московского колл-центра, где работают

\footnotetext{
${ }^{1}$ Подробные данные об участниках исследования доступны по запросу к автору.
} 
незрячие сотрудники, тифлопедагогами, сотрудниками Всероссийского общества слепых, преподавателями Кисловодского медицинского колледжа. Имена участников изменены.

\section{«Да, вы лежать должны с первой группой!»: медицинская модель инвалидности}

Исследователи медикализации показали, что медицина «заняла место» религии как «доминантная моральная идеология и институт социального контроля» в современных обществах (Conrad 1992:213). Питер Конрад подчеркивает, что медикализация связана в первую очередь с определением некоего явления в медицинских терминах (Ibid:211). Кроме того, медицина имеет общественно санкционированную власть освобождать «больного» от работы, замерять и подтверждать его трудоспособность, и в этом смысле - контролировать участие в профессиональной жизни общества (Parsons 1951: 453). «Правильное» поведение инвалида состоит в том, что он сидит дома на «щадящем режиме», освобожден от любых общественных ролей, кроме одной - роли больного. При этом инвалидность понимается как хроническая болезнь, которая дает пожизненную «отсрочку».

В рамках медицинской модели подчеркивается трагическое влияние увечья на стиль жизни человека и его отличия от «нормально функционирующих» людей. Образ человека с инвалидностью ассоциируется с «жалостью, страхом и благотворительностью», и такой человек в общественном сознании конституируется как объект опеки (Johnstone 2001: 16,17). В медицинской модели эти два аспекта - биологичность увечья и необходимость патерналистской заботы - оказываются прочно связаны. Человек с инвалидностью подлежит реабилитации, т.е. «восстановлению» до некого «нормального» состояния, но его роль пассивна: он является получателем услуг и, что важно в контексте статьи, не может быть автономным экономическим субъектом.

Патерналистское отношение к «инвалиду-как-больному» проецируется в экономическую и социальную сферы. Так, проекты трудоустройства незрячих (например, в сфере ручного труда, массажа, о которых речь пойдет далее) отражают взгляд на «слепых» как на группу, нуждающуюся в трудоустройстве, а не на отдельных участников рынка труда, имеющих уникальные профессиональные интересы и таланты. В образовании «инвалиды» понимаются как льготная группа. Кроме того, метафора болезни часто является ключевой в восприятии людей с инвалидностью на уровне взаимодействия «лицом к лицу». Например, в интервью были рассказаны ситуации, в которых человек с инвалидностью воспринимается как «заразный» или когда один тип инвалидности «притягивает» другие (обращаясь к человеку с белой тростью, прохожий может начать громко говорить, считая, что если человек испытывает ограничения по зрению, то он также плохо слышит). Примечательно, что «болезнь» воспринимается как статичное состояние. Эта перспек- 
тива не учитывает, например, того, что зрение может непрерывно, заметно или незаметно для самого человека улучшаться или ухудшаться, что отсутствие зрения может становиться заметным лишь в определенных социальных ситуациях. Таким образом, медицинская модель не включает «ситуационный и опытный компоненты инвалидности» (Oliver 1990:5).

Большое значение для восприятия окружающими, по нашим наблюдениям, играет видимость биологических или сенсорных отличий. По выражению Билла Хьюза, наша культура «окуляро-центрична», для нее важна видимость физического и психического совершенства, она направлена на «эстетическую нормализацию и ценность идеальных стандартов красоты» (Hughes 2002: 580). В этом смысле зримые признаки болезни (такие как отсутствие части тела, белая трость, кресло на колесах) более стигматизированы в обществе, чем невидимые (например, сердечно-сосудистые или иммунные заболевания), и нерефлективно могут считываться как нарушения культурного идеала.

\section{Советская трудовая модель и «профессиональные колеи» незрячих В СССР}

Многие страны в той или иной степени устанавливают и «замеряют» инвалидность через измерение трудоспособности человека (см.: Муравьева 2012: 156). В некоторых контекстах, однако, способность человека быть значимым агентом в производстве благ становится ключевым критерием инвалидности. Отдельные исследователи в связи с этим стали выделять трудовую модель инвалидности (Fieseler 2014:24). В советское время трудовые ресурсы служили важным критерием общественной ценности человека, а труд был «главной составляющей советского гражданства» (Rasell, Iarskaia-Smirnova 2014: 83). После Великой Отечественной войны те ветераны, которые не могли работать и не имели иных средств (трудового дохода, поддержки родственников), получали пенсию и, фактически, были обречены на нищету, поскольку занятость обеспечивала также доступ к ключевым благам (жилье, продовольственные карточки и пр.). Те же, кто мог работать, независимо от тяжести увечья, не считались инвалидами и активно вовлекались государством в процесс восстановления страны (Fieseler 2014).

Трудовая модель инвалидности в советские годы была гарантом занятости любого работоспособного человека, однако эта занятость в большинстве случаев имела форму заранее известных сценариев. Советские проекты занятости незрячих носили массовый характер и основывались на представлениях о способностях людей без зрения как некой гомогенной группе - в частности, их особой музыкальности или тактильной чувствительности,- чем на личном выборе. Советская трудовая модель инвалидности определяла четкие «профессиональные колеи» (Ильин 2015:516-517) для людей, имеющих увечья и способных к труду, в том числе для незрячих людей. Во-первых, труд таких людей понимался в первую 
очередь как ручной. Образцовым типом трудоустройства незрячих стали мануфактуры, специально создаваемые ВОС с 1920-х гг. и особенно в послевоенное время, о чем можно прочитать на интернет-сайтах сохранившихся до наших дней предприятий, считающих советский период своим «золотым веком». Таким путем советское правительство одновременно решало экономические задачи и реализовывало политику медицинской/трудовой реабилитации инвалидов («трудовой терапии»).

Сотрудники ВОС с ностальгией вспоминают советские времена, когда любой незрячий человек мог получить работу на специальной мануфактуре, занимаясь ручным производством валенок, ящиков, коробов, решеток, упаковки, электрических шнуров, бахил и стелек, кистей и щеток, перчаток, брайлевской литературы и пр. Государственный заказ на продукцию незрячих давал людям возможность работать за минимальную заработную плату и получать необходимый для выживания «социальный пакет»: согласно интервью, через год или два рабочие предприятия получали жилье, в среднем раз в два года - путевки в санатории. Предприятия становились центрами организации жизни рабочих с простроенной внутренней структурой пространства и времени, и практически отсутствующими внешними связями. О возникающих на их основе изолированных районах участники интервью говорили как о слепецких или тифлогородках:

...Во многих предприятиях были такие, ну, скажем так, тифлогородки, где около предприятия строился дом или несколько домов, магазины, вся, так сказать, инфраструктура, дорожки, огражденные перилами, чтобы люди ходили без тросточки... (Н., 49 лет, аппарат управления ВОС).

Помимо неквалифицированного труда, легитимными «профессиональными колеями» незрячих стали области, требующие специальной подготовки,- медицинский массаж и музыка. Для этих целей в послевоенное время были открыты специализированные средние учебные заведения, такие как Курский музыкальный колледж-интернат слепых (1954 г.) и профессиональная школа для незрячих массажистов в Кисловодске (1958 г.). Массовая профессионализация незрячих как массажистов и музыкантов, равно как и, например, профессиональная подготовка глухих в сфере актерского мастерства и визуальных искусств, соответствовала определенным представлениям государства о том, какие профессии подходят для людей с различными видами инвалидности.

Система трудового «распределения» после окончания учебного заведения была гарантом трудоустройства специалистов: «Тогда вуз конкретно распределял человека на работу. Человек приезжал, если ему не давали работу, он обращзался в обком партии, и вопрос решался» (Н., 49 лет). Однако не всегда процедура трудоустройства работала без перебоев. Массажистка Нора рассказывает, как на закате советского строя она училась на курсах компьютерной стенографии, организованных ВОС. 
Учащиеся осваивали навыки точной записи человеческой речи на специальной клавиатуре, не имеющей отметок, чтобы затем работать стенографистами на публичных мероприятиях: «...Когда мыз закончили... мы пошли в ЦП ВОС. Нам сказали: "Такого ещче не изобрели, не придумали"... А потом все компьютеры... выкинули просто» (Н., 45 лет).

\section{Политика инвалидности в постсоветские годы: болезнь человека или болезнь общества?}

В 1990-е гг. вместе со сменой политического строя исчезли и основания «трудового гражданства» - труд перестал быть центральным элементом общественного единства. Принятие либерального закона об инвалидах в 1995 г. не сопровождалось включением их в общество, так как само общество, по сути, превратилось в набор изолированных и дезориентированных индивидов. От групповой изоляции незрячие перешли к индивидуальной, подразумевающей «домашний режим» и выплату социальных пособий. Многие места массовой занятости незрячих (предприятия) перешли на «полуспящий режим», в то время как открытый рынок оказался не готов воспринять новых специалистов как полноценных экономических агентов. Характерно, что проблемы с занятостью связываются некоторыми участниками исследования с проблемами безработицы в стране в целом: «Ну, проблемь-то сейчас, они, наверное, у всех одинаковые, просто у нас еще немного отягощает то, что зрения нет вообще...» (В., 37 лет). На фоне общих сложностей с поиском работы, а также все большего проникновения рабочего пространства в приватную жизнь внеурочной занятости, переработок, необходимости отвечать на почту и звонки даже в нерабочее время - шансы на трудоустройство людей, помеченных стигмой инвалидности, оказываются мизерными.

На сегодняшний момент точной статистики по занятости людей с инвалидностью по зрению в России не существует. Н., сотрудник аппарата управления ВОС, рассчитывает общее число незрячих в стране, исходя из данных ООН, согласно которым доля инвалидов по зрению среди всех инвалидов в среднем составляет 8-9\%. Взяв общую цифру по всем инвалидам России (12,8 млн, он получает 1,1-1,2 млн инвалидов по зрению). Н. говорит о том, что порядка 200 тыс. из тех незрячих, которые состоят в ВОС,-это преимущественно инвалиды первой и второй групп, имеющие самые большие проблемы с трудоустройством в России. Инвалидов третей группы, особенно тех, кто могут вести приближенный к зрячему образ жизни («читать, писать, ездить на машинах»), он не относит к «инвалидам», так как их социальный статус гораздо ближе к статусу зрячих.

Размер пенсии москвича с первой группой инвалидности может составлять от 15 до 20 тыс. рублей; шансы трудоустройства на такой же оклад в Москве очень невелики: 
А что - пенсия хорошая в Москве по первой группе... Если по І группе, бессрочная, и отказаться от всего, чего можно, там что-то под 20 штук. На одного. Смысла вообще работать никакого нету (А., 34 года).

В такой ситуации инвалиду первой группы целесообразнее и экономичнее оставаться дома, чем выходить на улицу и искать работу. Образцовую жизненную стратегию, имплицитно навязываемую незрячему, можно описать как изоляция в домашних условиях при гарантии минимального уровня жизни:

Помните, был такой рассказ... он назывался «Дюймовочка». Там, помните, был такой сын жабы... Почему он такой толстый был? Кушал спал, кушал - спал. Я тоже кушаю - сплю, кушаю - сплю... (А., 28 лет).

Взгляд на людей с инвалидностью как на хронических пациентов с пожизненно прописанным «домашним режимом», распространен, несмотря на то что на уровне закона в постсоветское время сделан шаг в сторону социальной модели инвалидности. Текст Федерального закона (1995) формулирует проблему инвалидности одновременно как медицинскую/функциональную («нарушение здоровья со стойким расстройством функций организма») и социальную («ограничения жизнедеятельности»), каузальные причины которой лежат, скорее, в структурных условиях общества. Задача государства, согласно тому же закону, это «социальная защита инвалидов», понимаемая как «создание условий» для того, чтобы люди с инвалидностью имели «равные с другими гражданами возможности участия в жизни общества». Средством управления инвалидностью является «реабилитация», цель которой - социальная нормализация инвалидов («социальная адаптация, включая достижение ими материальной независимости»).

Программа реабилитации «назначается» человеку комиссией медикосоциальной экспертизы (МСЭ). По факту, она представляет собой схематично составленную бумагу (индивидуальную программу реабилитации и абилитации, ИПРА), которая, по замечанию участников исследования, нужна, прежде всего, чтобы получать бесплатные «технические средства реабилитации» (трость; тифло-плеер; «говорящий» градусник, будильник; грифель и бумагу для письма по Брайлю). Помимо такого рода «медицинской» реабилитации, незрячий имеет право на социальную реабилитацию в специальных центрах, где можно бесплатно посещать творческие и спортивные кружки, приобретать навыки домоводства и самообслуживания, пространственного ориентирования и GPS-навигации, работы на компьютере.

Наиболее проблемный пункт программы реабилитации - профессиональный. В теории, куда бы «инвалид» ни приходил учиться или устраиваться на работу, ИПРА должна служить своеобразной инструкцией для учебного учреждения или работодателя, помогающей понять, что необходимо дать такому студенту/сотруднику, чтобы ему было удобно учиться/ работать. Однако на деле в программе реабилитации нередко пишется 
стандартная фраза про то, что человек может работать на предприятиях со специально оборудованным рабочим местом, что проблематично, если таких мест на предприятии нет (И., 42 года). Хуже, если в документе указываются конкретные вакансии, на которые может претендовать предъявитель, что ограничивает его возможности на рынке труда:

А если у тебя первая группа, то тебе особо-то там и не напишут, что ты можешь... Ну, то есть мы попросили, и нам написали, что он может работать в колл-центре. А чтобы попасть в медицинский колледж... такая должна быть прям запись... Естественно, с первой группой не делают такие записи... (М., мать участника, зрячая).

Процесс присвоения группы инвалидности становится зоной столкновения интересов, интерпретаций, манипуляций, коррупции, а также мучительных дилемм самих незрячих и их близких. А. и его мама оказались в ситуации выбора: сохранить ли статус бессрочной группы (пожизненной с правом на более высокую пенсию) или же «попросить» изменить статус до второй группы, открывающий более разнообразный диапазон профессий, но требующий ежегодного сбора справок и походов по врачам для его подтверждения (А., 28 лет). Похожая ситуация возникла у отца одного из участников исследования, 18-летнего Д.:

Я могу рассказать на опыте отца. Он работает сейчас в детской краевой клинической больнице в Краснодаре, в хозотделе. ... У него 2 группа, хотя по факту должна быть первая, но он ее не проходит, потому что ему сказал работодатель: «Если ты получишь первую группу, то мы тебя не сможем держать на работе, потому что с первой группой не положено».

Необходимость идти на компромисс - сохранить социальные привилегии и высокую пенсию или возможность работать - также отмечается исследователями, работающими с инвалидами в других восточно-европейских странах (Zaviršek 2014: 194).

\section{«Профессиональные колеи» людей с инвалидностью по зрению}

По расчетам нашего информанта, порядка 14800 человек работают на открытом рынке труда, 5300 - на предприятиях ВОС, еще 2 тыс. незрячих учатся на очных программах в вузах - что в совокупности составляет порядка трети членов ВОС трудоспособного возраста (Н., 49 лет). Найти общую информацию о работе еще 1 млн людей, имеющих группу инвалидности по зрению и не состоящих в ВОС, по-видимому, на текущий момент нельзя. Как и в советское время, в современной России незрячие люди работают не повсеместно, а в «сложившихся» нишах (лечебный массаж и музыка), и только единицам удается устроиться на работу на «нетипичные» позиции 
(бизнес-аналитик, программист, переводчик). Эти безусловно важные, но по-своему безальтернативные «ниши» отчасти связаны с отношением к незрячим как к людям, обладающим особыми тактильными и слуховыми способностями:

У нас есть музыкальный специальный и массажный специальный колледж. Туда берут по принципу слепоты. Не то, что у тебя талант! У тебя могут быть руки, там, недоразвиты, но ты слепой и можешь идти на массажиста. Тебе, может, медведь оттоптал все уши, и ты совершенно не музыкальный человек, но... (М., тифлопедагог).

Звукорежиссер К. говорит о том, что для людей, потерявших зрение в раннем возрасте, слух является основой навигации: практически любой такой человек «слышит стены», то есть ориентируется в помещении и на улице, считывая отражения звуков от разных поверхностей. Однако он и еще несколько участников исследования отмечают, что хороший слух как главное сенсорное устройство рано ослепшего человека далеко не всегда приводит к особой «музыкальности» его обладателя и, как следствие, к избранию карьеры музыканта (В., тифлопедагог; К., 27 лет; А., 28 лет).

Специальность массажиста также часто избирается по принципу «а куда еще?». Так, 37-летний шахтер В., получивший первую группу инвалидности в 2015 г., комментирует, что, кроме специальности массажиста, «не смог найти ничего, чтобы нормально жить: чем заняться, именно когда уже первая группа, когда уже край?» (В., 37 лет). О Кисловодском медицинском колледже люди, имеющие инвалидность по зрению, узнают через знакомых, в интернете или через первичную организацию ВОС. Несмотря на отличные отзывы о качестве образования в колледже, которое включает трехлетнее обучение клиническим дисциплинам, а также разным техникам массажа, в интервью 19-летние студенты отмечают: «Большинство людей здесь учатся не потому, что прям хотят в медицину, а потому что больше выбора нет» (И., 19 лет); «В том-то и дело, что альтернатив для слабовидящих очень мало. У нас, ну, грубо говоря, либо ты массажист, либо немассажист» (Д., 19 лет).

Еще одним проектом трудоустройства «по принципу слепоты» стала инициатива московского правительства, которое с 2009 г. финансировало с переменным успехом организацию нескольких колл-центров. Телефонные опросы, таким образом, стали еще одной опцией в пакете вакансий, на которые незрячие смогли легитимно претендовать. Некоторые участники исследования - вероятно, ищущие работу через сети незрячих знакомых перепробовали все эти опции, поэтому их биографии пестрят разнородным и вместе с тем стандартным списком занятий: «Я работала сначала на заводе для незрячих... После школь я училась на массажиста... А потом я, когда ушла с завода, работала в колл-цеентре» (А., безработная).

Многие незрячие, «варящиеся» в своем кругу, видят свою профессиональную жизнь лишь в проложенных в обществе «профессиональных 
колеях». Согласно исследованию, проведенному среди выпускников московских вузов в 2014 г., незрячие студенты показывают достаточно стереотипные ожидания относительно той деятельности, которой они хотели бы заниматься: $38 \%$ - стать операторами колл-центров, $37 \%$ - работать на предприятиях и лишь $21 \%$ - работать по приобретенной специальности (Лапшин 2014). Такие результаты показательны: несмотря на получение высшего образования, которое сегодня незрячие могут получить в том числе на льготной основе, расширения их карьерных траекторий в новые области не происходит по окончании вуза большая часть выпускников собирается (часто вынужденно) устроиться на те же вакансии, которые были доступны им и прежде.

Известная незрячим схема трудоустройства на предприятиях ручного труда ВОС (учебно-производственных предприятиях (УПП) или «хозяйственных обществах») приводит многих из них сюда в тот или иной период жизни. В постсоветские годы УПП были оторваны от «источника питания»: государственные заказы на продукцию незрячих прекратились, отменены почти все налоговые льготы. Большая часть предприятий испытала сложности при переходе на открытый рынок и необходимости конкурировать с другими компаниями. Часть учреждений ВОС стала сдавать площади в аренду. Многие предприятия продолжили номинально существовать, сократив рабочую неделю до нескольких дней и выплачивая рабочим мизерные зарплаты. Так, А., рассказывая о работе на московском УПП, говорит, что его зарплата там составляла 1000-1500 рублей в месяц (А., 28 лет). На некоторых предприятиях зарплаты выше и приближаются к размеру московской пенсии - но это касается в первую очередь тех, кто имеет остаточное зрение и возможность работать на более сложных заданиях: «Конечно, УПП бывают разньле. Есть [название предприятия], где платят хорошо, но там такая мелкотура, там такие винтики-ипунтики мельчайшие» (А., 28 лет).

Молодые, особенно те, кому повезло найти более интересное дело, говорят о работе «на ленте» как о скучном, рутинном занятии, «мартышечьем» или «обезьяньем» труде (И., 42 года):

Там, вот, стоит бедная несчастная... слабовидящая $<\ldots>$ На станке клепает крышки для коньяка. За смену там что-то 4000 крышек должна выработать. То есть ангар стоит, она - в наушниках, потому что шум там... потеря слуха гарантирована через какое-то время. Физиологически чисто. И вот у нее: педалька - педалька - рычаг, педалька - рычаг. Восемь часов за смену (В., тифлопедагог).

По мнению А., 34-летнего сотрудника совета по делам молодежи при ВОС, инвалиды по зрению, сталкивающиеся с проблемами на «открытом рынке», нередко устраиваются в организации Общества. Так, несколько тысяч незрячих в составе управленцев, преподавателей, администраторов, реабилитологов трудоустроены в центральной, региональных и местных организациях ВОС. Некоторые из них формируют теплую, проактивную команду: таков, например, молодежный отдел и команда «Радио ВОС», в руках которых работа 
буквально «кипит» (К., 27 лет). Система ВОС и «профессиональные колеи» служат той протоптанной и знакомой самим незрячим тропой, на которой они могут безопасно передвигаться, получая пусть не всегда болышие, но гарантированные деньги, а также - что часто тематизируется в интервью-общение, возможность «быть полезным... жить, одним словом» (В., 37 лет).

\section{«Открытый рынок»: законодательные и социальные проблемы}

Законодательство предоставляет налоговые льготы, т.е. поддерживает экономически только те предприятия, где инвалиды составляют половину и более. Компании, которые могли бы трудоустроить одного или несколько сотрудников не имеют экономических стимулов, но, более того, обязаны текущим законом предоставить им особые условия труда: укороченный рабочий день (35 часов) с сохранением обычной зарплаты, 30 дней отпуска, в случае незрячих - установить специальные озвучивающие компьютерные программы, тактильную разметку и брайлевские подписи на кабинетах, в лифтах. Исполнение щедро прописанных в законе «прав инвалидов» ложится на плечи работодателей (хотя часть расходов может взять на себя и государство), тем самым способствуя отказу человеку с группой при трудоустройстве.

Механизм «квотирования» рабочих мест принуждает предприятия свыше 100 человек иметь в своем составе 2-4\% инвалидов (Федеральный закон 1995: Ст. 21). На квотированные места охотнее берут людей с третьей группой и высшим образованием, а также тех, кто «хорошо разбирается в компьютерах» (А., 28 лет). Предпочитают выплачивать небольшие (510 тыс. рублей) административные штрафы за несоблюдение квоты. Вторая стратегия, характерная также для работодателей в других постсоветских странах (Phillips 2014), заключается в том, чтобы нанимать «инвалидов» по квоте фиктивно - т. е. собирать трудовые книжки, выплачивая им небольшие регулярные «зарплаты». «Мертвые души», или, как их еще называют, «коты-мурзики» (Н., 49 лет), получают пару тысяч рублей в месяц за ту работу, которую никогда не совершали.

Помимо того, что работодателю непонятно экономически, зачем устраивать на работу человека с инвалидностью по зрению, не имея опыта общения такого рода, он руководствуется стереотипами. Представления и практики рекрутинга незрячих в тех областях, которые являются для них профессиональной terra incognita, лучше всего обнажают медицинскую (патерналистскую) модель (само)восприятия таких людей. Обе стороны - и работодатели, и кандидаты - разделяют единый набор представлений о том, что гражданская роль человека с инвалидностью отличается от гражданской роли «здорового» человека. Незрячий человек чаще всего воспринимается как объект государственной (благотворительной) опеки, и лишь в единичных случаях - как автономный экономический 
субъект. Нередко сами участники исследования, характеризуя представления людей, имеющих инвалидность, делят их на «основную массу» пассивных и единицы «активных», на тех, кто «жалеет себя, жалуется, обвиняет», и тех, кто «взял ответственность за свою жизнь» (Л., 28 лет; В., супервайзер в коллцентре; В., тифлопедагог). Так В., 32-летний юрист, безуспешно пытающийся найти работу в небольшом городке в Башкирии после окончания вуза, рассказывает о страхах работодателей перед сотрудниками-инвалидами. Он подчеркивает неспособность доверить незрячему «ответственную» работу:

Пару раз ходил [по работодателям], потом так еще по газетам искали, тоже сам вот в интернете постоянно ищу... Люди просто боятся. Это же не просто там - прийти, полы помыть. Не дай бог, если кто-нибудь бумажку вытащит - и все. Если это компания, то компания рассыплется. Если это адвокат, то, естественно... у него вся защита развалится. То есть побаиваются.

Ответственность воспринимается как отличительное свойство зрячих людей, в то время как со слепым надо возиться (Н., 49 лет) как с ребенком или больным. Опека над незрячим становится само собой разумеющимся способом совладания с его инвалидностью: со стороны государства (пенсии), родителей («Родители - это беда! Слава богу, моя мама меня... в покое оставила» Л., 28 лет), образовательных и профессиональных институтов (специальные условия и заниженные стандарты), прохожих на улице (патернализм, граничащий с брезгливостью). В этой ситуации незрячий или усваивает роль «капризного больного», благодаря чему некоторые работодатели всерьез боятся, что не смогут уволить «инвалида», что он будет «сутяжничать, качать права» (Н., 49 лет), или выступает в роли «трансгрессора», то есть нарушителя отведенной для него роли.

«Капризный больной» не привык к контролю за собственной жизнью, как такие незрячие, которых 28-летняя пианистка Л. не без пренебрежения называет «моральными инвалидами»: «Они привылли... ну, что к ним относятся как-то так особенно, и они... пользуются этим... Они обижаются на весь окружающий мир, считают, что все им обязаны. Или, там, все у них плохо». Интервью с администратором колл-центра, в котором работают преимущественно незрячие, показывает, какого рода проблемы для «профессионального мира» создают такие сотрудники: «У нас были такие, которые говорили: вот, у вас тоже будут приходить проверки, давайте я у вас устроюсь, а когда к вам проверка придет, я буду к вам приезжать». Несколько участников отмечают, что вместе с «основной массой» людей, которые привыкли «жалеть себя», есть единицы тех, кто «позитивны и активны», и главное - кто берет ответственность за свою жизнь и здоровье: они могут «соревноваться с обычными людьми», «делать что-то "на уровне"», «для них не существует этого барьера» (Л., 28 лет; В., супервайзер в колл-центре):

Вот, я приятельствую с парнишкой, он вообще один из ведущих бизнесаналитиков... И никого не волнует - слепой-не слепой, у него есть 
голова. У него есть образование... Вот таких вот - единицы. Но такие тоже есть (А., 34 года).

Позитивность, ответственность, самостоятельность и готовность к борьбе можно считать ключевыми характеристиками «трансгрессора», пытающегося сойти с протоптанной тропинки и пробиться в интересную для него профессиональную сферу - за границы, отведенные невидимой рукой его группе.

\section{Заключение}

Взгляды на инвалидность, будь то болезнь, трудовые возможности человека или проблемы общественного устройства, влияют на то, как складывается профессиональная судьба конкретного человека, подпадающего под эту языковую, юридическую и социальную категорию. В ходе анализа были обнаружены как административные проблемы, с которыми незрячий человек сталкивается при устройстве на работу, так и более широкие социальные предубеждения, которые задают обыденные представления в отношении людей с инвалидностью. Эти представления связаны с экзотизацией человека без зрения, например, восприятием его как обладателя особой тактильной чувствительности/музыкальности. Часто отношение к незрячему имеет патерналистский оттенок, то есть складывается по модели взрослый-ребенок, опекун-зависимый. Незрячий воспринимается как объект постоянной заботы, а не личность, обладающая компетентностью и автономией распоряжаться собственной жизнью, в том числе профессиональной. Государственная политика отражает это отношение: незрячие люди не выбирают карьерную траекторию самостоятельно, их «трудоустраивают» в соответствии с «наиболее подходящими» для их статуса профессиями.

Профессионализация незрячих в России редко становится личным делом конкретного человека, но почти всегда отвечает некоторым конвенциальным представлениям о «правильной» работе для этой группы. Эти «тропки» слишком узки, немногочисленны и производят феномен профессиональной сегрегации. При этом проблема ограниченности репертуара профессий, на которые люди с инвалидностью могут реально устроиться, практически не обсуждается в современных дискурсах о правах инвалидов на труд.

\section{Выражения благодарности}

Выражаю благодарность Российскому фонду фундаментальных исследований за финансовую поддержку в проведении исследования (грант 15-06-05583, руководитель - Е.Э. Носенко-Штейн), а также всем участникам, согласившимся поделиться уникальным опытом. 


\section{Список источников}

Добровольская В.Е. (2016) Репрезентация инвалидов в русском фольклоре. Семинар no disability studies, Москва: Институт этнологии и антропологии.

Ильин В. (2015) Профессия как индивидуальная жизненная колея: концептуализация категории. Журнал исследований сощиальной политики, 13 (4): 515-528.

Лапшин К.А. (2014) Отношенческие барьеры при трудоустройстве молодых инвалидов по зрению. Доступно по ссылке: https:/goo.gl/YHa5Vo (дата обращения: 2 апреля 2016).

Московичи С. (1998) Машина, творящая богов, М.: Захаров.

Муравьева М.Г. (2012) Калеки, инвалиды или люди с ограниченными возможностями? Обзор истории инвалидности. Журнал исследований социиальной политики, 10 (2): 151-166.

Федеральный закон (1995) О социиальной защите инвалидов в Российской Федерации № 181-Ф3 от 24.11.1995.

Conrad P. (1992) Medicalization and Social Control. Annual Review of Sociology, (18):209-232.

Fieseler B. (2014) Soviet-style Welfare. The Disabled Soldiers of the 'Great Patriotic War'. M. Rasell, E. Iarskaia-Smirnova (eds.) Disability in Eastern Europe and the Former Soviet Union: History, Policy and Everyday Life, London: Routledge: 18-41.

Freidson E. (1988) Profession of Medicine: A Study of the Sociology of Applied Knowledge, Chicago: University of Chicago Press.

Hughes B. (2002) Bauman's strangers: Impairment and the Invalidation of Disabled People in Modern and Post-Modern Cultures. Disability \& Society, 17 (5): 571-584.

Johnstone D. (2001) An Introduction to Disability Studies, $2^{\text {nd }}$ Ed., London: David Fulton Publishers.

Oliver M. (1990) The Politics of Disablement. Critical Texts in Social Work and the Welfare State, Basingstoke: Palgrave Mackmillan.

Parsons T. (1951) Illness and the Role of the Physician: a Sociological Perspective. American Journal of Orthopsychiatry, (21): 452-460.

Phillips S. (2014) Citizens or 'dead souls'?: An Anthropological Perspective on Disability and Citizenship in Post-Soviet Ukraine. M. Rasell, E. Iarskaia-Smirnova (eds.) Disability in Eastern Europe and the Former Soviet Union: History, Policy and Everyday Life, London: Routledge: $165-184$.

Rasell M., Iarskaia-Smirnova E. (eds.) (2014) Disability in Eastern Europe and the Former Soviet Union: History, Policy and Everyday Life, London: Routledge.

Zaviršek D. (2014) Those Who do not Work Shall not Eat!: A Comparative Perspective on the Ideology of Work within Eastern European Disability Discourses. M. Rasell, E. Iarskaia-Smirnova (eds.) Disability in Eastern Europe and the Former Soviet Union: History, Policy and Everyday Life, London: Routledge: 184-203. 
Alexandra Kurlenkova

\title{
'DEAD SOULS', 'THE WHIMSY SICK' AND 'TRANSGRESSORS': NON-SIGHTED PEOPLE IN 'PROFESSIONAL SOCIETY' THROUGH THE LENS OF DISABILITY MODELS
}

\begin{abstract}
This article examines the participation of non-sighted people in the professional world through the lens of medical, social and production-related models of disability. The central idea here is these models emerge as a product of social and legal conventions. At the same time, state policies are defined by these models, which also affect the (self-)perception of the non-sighted. Based on a qualitative analysis of more than twenty interviews with nonsighted people, I show that attitudes towards this 'group' today are heavily influenced by a paternalistic medical model of disability that constructs the image of a non-sighted person as a sick individual in need of rest that should be encouraged to 'stay at home'. Private businesses rarely see any economic benefit in hiring 'the disabled', preferring either to pay state fines or use fake employment scams. The range of extremely narrow legitimate professional options on offer to the non-sighted dates back to the Soviet period, when the main employment on offer was mostly monotonous and manual work in factories for less than minimal wage. The non-sighted were also employed in massage and music spheres, as well as teaching at specialized schools. What emerged is that the basis for designating these spheres as 'proper' jobs for the non-sighted is the notion that the non-sighted constitute a homogeneous group with similar professional abilities and ambitions. While many non-sighted people follow these 'beaten paths', others take on the role of 'transgressors', breaking away from well-worn professional trails and forging new career pathways.
\end{abstract}

Keywords: Disability models, the nonsighted, the sighted, the disabled, labour citizenship, medicalization, sick role

DOI: 10.17323/727-0634-2017-15-2-235-250

\section{References}

Conrad P. (1992) Medicalization and Social Control. Annual Review of Sociology, (18):209-232.

Fieseler B. (2014) Soviet-style Welfare. The Disabled Soldiers of the 'Great Patriotic War'. M. Rasell, E. Iarskaia-Smirnova (eds.) Disability in Eastern Europe and the former Soviet Union: History, Policy and Everyday Life, London: Routledge: 18-41.

\footnotetext{
Alexandra Kurlenkova - Kandidat nauk (PhD) in history, MA (Bioethics), research assistant at the Group of Medical Anthropology, Institute of Ethnology and Anthropology RAS, Moscow, Russian Federation. Email: askurlenkova@yandex.ru
} 
Federal Law (1995) O sotsial'noy zashchite invalidov v Rossiyskoy Federatsii [On Social Protection for People with Disabilities in the Russian Federation] N181-FZ from 24.11.1995.

Freidson E. (1988) Profession of Medicine: a Study of the Sociology of Applied Knowledge, Chicago: University of Chicago Press.

Hughes B. (2002) Bauman's Strangers: Impairment and the Invalidation of Disabled People in Modern and Post-modern Cultures. Disability \& Society, 17 (5): 571-584.

Il'in V. (2015) Professiya kak individual'naya zhiznennaya koleya: kontseptualizatsiya kategorii [Profession as an Individual Life Track: Category Conceptualization]. Zhurnal issledovanii sotsial'noi politiki [The Journal of Social Policy Studies], 13 (4):515-528.

Johnstone D. (2001) An Introduction to Disability Studies, 2nd Ed., London: David Fulton Publishers.

Lapshin K. A. (2014) Otnoshencheskie bar'ery pri trudoustroystve molodykh invalidov po zreniyu [Attitude Barriers during Recruitment of Young Visually Impaired People]. Available at: https://goo.gl/YHa5Vo (accessed 2 April 2016).

Moscovici S. (1998) Mashina, tvoryashchaya bogov [The Machine for the Creation of Gods], Moscow: Zakharov.

Muravyeva M. G. (2012) Kaleki, invalidy ili lijudi s igranichennymi vozmozhnostjami? Obzor istorii invalidnosti [Cripples, Invalids or People with Disability? A Review of the History of Disability]. Zhurnal issledovanii sotsial 'noi politiki [The Journal of Social Policy Studies], 10 (2): 151-166.

Oliver M. (1990) The Politics of Disablement. Critical Texts in Social Work and the Welfare State, Basingstoke: Palgrave Mackmillan.

Parsons T. (1951) Illness and the Role of the Physician: a Sociological Perspective. American Journal of Orthopsychiatry, (21): 452-460.

Phillips S. (2014) Citizens or 'Dead Souls'?: an Anthropological Perspective on Disability and Citizenship in Post-Soviet Ukraine. M. Rasell, E. Iarskaia-Smirnova (eds.) Disability in Eastern Europe and the former Soviet Union: History, Policy and Everyday Life, London: Routledge: $165-184$.

Rasell M., Iarskaia-Smirnova E. (eds.) (2014) Disability in Eastern Europe and the former Soviet Union: History, Policy and Everyday Life, London: Routledge.

Zaviršek D. (2014) Those Who Do not Work Shall not Eat!: a Comparative Perspective on the Ideology of Work within Eastern European Disability Discourses. M. Rasell, E. IarskaiaSmirnova (eds.) Disability in Eastern Europe and the former Soviet Union: History, Policy and Everyday Life, London: Routledge: 184-203. 